\title{
Nem tão perto nem tão longe: Jauss e Bakhtin, cotejos e confrontos
}

\section{Eliane Santana Dias Debus}

Professora doutora do Programa de Pós-Graduação

em Ciências da Linguagem, da Universidade do Sul de

Santa Catarina, em Tubarão (elianedebus@hotmail.

com).

Resumo: Mapeamento das similitudes e contrastes Abstract. This text tries to map the similarities and nas ideias desenvolvidas por Mikhail Bakhtin e Hans Robert Jauss, no tocante ao diálogo entre texto e leitor, para uma demonstração de duas posições capazes de, por um lado, romper com a imanência textual e, de outro, colocar na linha de frente, mesmo de modo distinto, aquele a quem se way. destina a obra literária: 0 leitor. contrasts in the ideas developed by Mikhail Bakhtin and Hans Robert Jauss in terms of the dialogue between text and reader. It presents these two positions which break with textual immanence and put the reader in the forefront, albeit in a distinctive

Key words: Reader; literary work; dialogue; Jauss;

Palavras-chave: Leitor; obra literária; diálogo; Bakhtin Jauss; Bakhtin 

Para a análise da experiência do leitor ou da "sociedade de leitores" de um tempo histórico determinado, necessita-se diferençar, colocar e estabelecer a comunicação entre os dois lados da relação texto e leitor (JAUSS, 1979).

O discurso nasce no diálogo como sua réplica viva, forma-se na mútua orientação dialógica do discurso de outrem no interior do objeto. A concepção que o discurso tem de seu objeto é dialógica (BAKHTIN, 1993).

Os estudiosos Mikhail Mikháilovich Bakhtin (1895-1975) e Hans Robert Jauss (-1997) marcaram e contribuíram, cada qual à sua maneira, para os estudos literários contemporâneos. Entre as ideias e as reflexões desses dois estudiosos algumas centelhas se cruzam apesar do tempo que os separa. O que nos parece ponto de cruzamento encontra-se no processo de dialogização desenvolvido por ambos: Bakhtin, pelo diálogo com a tradição; e Jauss, pelo diálogo com o leitor. Para o primeiro, o texto deve ser vislumbrado na sua tradição literária e na sua comunicabilidade, pois toda produção textual presente incorpora, de forma mais ou menos intensa, a produção passada. Para o segundo é o leitor que, por meio da leitura, estabelece a relação dialógica com o texto.

A intenção primeira de nossa leitura objetiva destacar, nas ideias desenvolvidas por ambos, as similitudes e os contrastes, no que diz respeito ao processo de dialogização. Com isso, busca-se evidenciar duas posições que rompem com a imanência textual e colocam na linha de frente, mesmo de modo distinto, aquele a quem se destina a obra literária: o leitor.

É necessário lembrar que, desde o século XIX até os nossos dias, as análises e os estudos literários enveredaram por rumos diversificados que, em síntese, podem ser definidos como se ligando, sucessivamente, aos três elementos que constituem o fato literário: num primeiro momento, concentra-se na produção da obra, destacando a figura do autor e o seu contexto histórico 
(críticas biográficas e deterministas); num segundo momento, sobrevalorizaram-se o texto e o que ele tinha para dizer por si só, confiante na sua autossuficiência, em uma visão imanentista que se utilizou da linguística como ciência prioritária (Formalismo Russo, New Criticism e mesmo a Crítica Estilística, para chegar ao Estruturalismo), voltando-se as pesquisas, dessa forma, para o polo da textualidade, em detrimento do aspecto comunicativo. Bakhtin, contemporâneo ao formalismo, não segue essa corrente, privilegiando o aspecto comunicativo do texto. A partir das teses desenvolvidas por Jauss, no final da década de 60, começou-se a enfatizar a figura do leitor, ao privilegiar a relação autor-obra-público.

Bakhtin começa a publicar suas reflexões na segunda década do século $\mathrm{XX}$, período de grande efervescência cultural, regido pelo futurismo e por outras vertentes literárias, enquanto os estudos literários vivem sob a égide do formalismo. Sua produção científica está vinculada ao espaço da pesquisa docente, como professor que era, tendo atuado ora no Instituto Pedagógico de Saransk, ora em colégios locais de Kímri, até culminar sua carreira na Universidade de Saransk. Em Problemas da poética em Dostoiévski (1929), o pensador vai trazer para a discussão literária termos até então inexistentes, como polifonia e carnavalização. Suas obras ficam, por muito tempo, restritas ao Ocidente, e somente a partir de1960 a Europa vai entrar em contato com a tradução de seus textos.

No Brasil, no caso da estética da recepção, os primeiros ensaios são introduzidos em 1979, por Luiz Costa Lima no livro $A$ literatura e o leitor. Quase que simultaneamente, os escritos de Bakhtin começam a ser divulgados, principalmente com a tradução, em 1981, de Problemas da poética em Dostoiévski. Para Zilberman, essas publicações contribuíram para os estudos literários no Brasil, por diversificar "as opções de investigação, enquanto se encerrava o ciclo estruturalista, tão marcante e quase hegemônico durante a década de 70 " (ZILBERMAN, 1989, p.6). 
Jauss vivencia a revolução nos costumes da década de1960, a emergência dos movimentos estudantis e as adaptações e reformas universitárias motivadas por essas transformações. Autor de alguns ensaios sobre a literatura medieval, suas ideias realmente tornam-se públicas após a conferência inaugural do ano letivo na Universidade de Constança, em 13 de abril de 1967, denominada de Was ist und zu welchem ende atudiènt man literaturgeschichte? (O que é e com que finalidade se estuda história literária?). Sem dúvida e de modo declarado, Jauss retoma dialogicamente o questionamento de Friedrich Schiller quando da sua aula inaugural, cento e setenta e oito anos antes, na Universidade de Jena, Was heifst und zu welchem ende studiert man Universageschichte?(O que significa e com que propósito se estuda história universal?). Jauss, provocativamente, desenvolve sete teses através das quais se propõe "fundamentar metodologicamente e reescrever a história da literatura" (JAUSS, 1994, p.23), pois seu objetivo não consiste em banir a história dos estudos literários, mas reorganizá-la sob outro viés.

Em boa parte de seus ensaios, os dois estudiosos revisam criticamente as tendências teóricas de sua época no que se refere à linha tradicional por elas seguida. Bakhtin critica, sobretudo, a filosofia da linguagem, a linguística e a estilística; e Jauss se reporta, em especial, aos modelos metodológicos adotados na construção da história da literatura.

A crítica de Bakhtin a essa tríade resulta em elas operarem com dois polos do discurso: o sistema da linguagem única e o indivíduo que fala, voltando-se, assim, para a "unidade na adversidade". Esse sistema fechado de língua única veta a interação dialógica no discurso, bem como a instauração do plurilinguismo, reflete o teórico russo. A proposta de Bakhtin, ao contrário, contempla a língua em sua multiplicidade, como fenômeno concreto e "ideologicamente saturado" que garante um maximum de compreensão mútua; diverso do minimum abstrato da língua que resulta num minimum de compreensão (BAKHTIN, 1993, p.81).
${ }^{1}$ A conferência foi, logo no mesmo ano, publicada em livro com o título Literaturgeschichte als provokation der literaturwissenschaft e, com alterações e acréscimos posteriores, encontra-se traduzida no Brasil pela editora Ática (1994) com o título $A$ história da literatura como provocação à teoria literária. 
Bakhtin afirma que, ao lado das forças centrípetas que colaboram para unificar e centralizar a língua, caminham as forças centrífugas, que estratificam e descentralizam a língua. Os gêneros poéticos seriam os representantes das forças centrípetas e os gêneros prosaicos os representantes das forças centrífugas. Assim, o fenômeno dialógico do discurso em suas diferentes formas e graus não é explorado pela filosofia da linguagem, pela linguística ou pela estilística (BAKHTIN, p.82).

Jauss, por seu turno, no levantamento crítico da pré-história da ciência literária, opõe-se aos dois modelos metodológicos adotados pelos historiadores da literatura. O primeiro modelo ordena o material literário "segundo tendências gerais, gêneros e 'outras categorias', para então, sob tais rubricas, abordar as obras individualmente, em sequência cronológica" (JAUSS, 1994, p.6). O objeto desse modelo é, na maioria das vezes, a literatura moderna, o que por si só provoca uma dificuldade seletiva na medida em que, inserida no contexto atual, está em constante desenvolvimento, ficando difícil divisá-la no seu conjunto. O segundo modelo adota o padrão da Antiguidade Clássica, ordenando o material literário de forma unilinear, "seguindo a cronologia dos grandes autores e apreciando-os conforme o esquema 'vida e obra'" (JAUSS, 1994, p. 6), sendo o objeto desse modelo o cânone clássico.

$\mathrm{O}$ estudioso alemão ainda argumenta que a filosofia da história do século XIX, caracterizada por sua visão progressista, legou à história da literatura uma metodologia voltada para um painel de época em que as obras anteriores seriam mero trampolim, "estágios" para as gerações posteriores; tal posicionamento pressupõe um privilégio da última em relação às obras antecedentes. Já a influência da escola positivista e da escola idealista na história da literatura contribuiu para o afastamento entre a estética e a história. As teorias literárias desenvolvidas pelo marxismo e pelo formalismo, por sua vez, privam a literatura da dimensão de sua recepção e de seu efeito, pois elas ignoram a figura do leitor. $\mathrm{O}$ autor acredita ser 
possível, através do leitor, destinatário primeiro da obra, reatar os fios entre o "fenômeno passado à experiência presente" (JAUSS, 1994, p. 23), entre os aspectos estéticos e os aspectos históricos ${ }^{2}$.

Jauss propõe uma história da arte e da literatura fundada em outros princípios: as análises literárias deveriam mudar o enfoque, não mais se centrando no texto ou no autor e sim no que denominou de "terceiro estado": o leitor. Tal perspectiva colocaria em foco a figura do sujeito produtor (destinador) interagindo com a do consumidor (receptor). A arte obedeceria, assim, a uma função dialética: formadora e modificadora de percepção (ZILBERMAN, 1989, p.32).

Para Jauss, a historicidade da obra literária se consolida pela atualidade que é determinada pelo leitor, pois a historicidade do texto não depende, nesse caso, da época em que ele foi escrito, mas do momento em que foi lido. Essa atitude rompe com a noção da cadeia temporal, uma vez que o autor e a obra começam a fazer parte da história no momento em que são lidos, no momento em que são aceitos pelo público leitor.

Em sua primeira tese, o autor enfatiza a relação dialógica entre o leitor e o texto, que constitui a produção literária. Desse ponto de vista, a obra nunca é monológica ou atemporal: "Ela é, antes, como uma partitura voltada para a ressonância sempre renovada da leitura, libertando o texto da matéria das palavras e conferindo-lhe existência atual" (JAUSS, 1994, p.25).

Essa metáfora musical, se assim se pode chamar, empregada por Jauss, aproxima-se da imagem metafórica utilizada por Bakhtin ao introduzir o termo polifonia:

A imagem da polifonia e do contraponto indica apenas os novos problemas que se apresentam quando a construção do romance ultrapassa os limites da unidade monológica habitual, assim como na música os novos problemas surgiram ao serem ultrapassados os limites de uma voz (BAKHTIN, 1981, p.16).
${ }^{2}$ Jauss foi duramente criticado pelo seu modo de encarar a história literária, devido à inviabilidade de constatar a recepção das obras ao longo da história, pela ausência e dificuldade de coletar testemunhos históricos individuais de leitura, bem como pela contaminação estruturalista num método que se caracterizava como antiestruturalista. 
Assim, o termo polifonia é utilizado para designar o processo pelo qual se instala, no romance, uma multiplicidade de vozes plenivalentes e consciências independentes. As várias consciências não são reduzidas a um porta-voz cuja função é exercer um papel denominador e dominador da articulação; essas vozes interagem e são interdependentes no contexto do discurso. A imagem de cordão umbilical, utilizada por Bakhtin, parece ser propícia para descrever o fenômeno da polifonia, o qual só pode ocorrer quando a consciência da personagem se mostra individualizada e apresenta uma visão não acabada de mundo, rompendo, dessa forma, com o cordão umbilical do criador-autor.

Em sua segunda tese, Jauss argumenta que a experiência literária pressupõe um "saber prévio". A obra não se apresenta ao leitor como novidade total, ela se reporta ao "já lido", é eco de outros textos, de outros contextos da experiência leitora. Assim, desperta e aguça, no público leitor, expectativas quanto ao meio e fim do tecido narrativo.

Tal pensamento aproxima-se das ideias desenvolvidas por Bakhtin, para o qual todo discurso, ao tomar determinado objeto, já o encontra povoado pelo discurso de outro, carregado de julgamentos e opiniões alheias, envolvido pela "atmosfera do já dito" de uma concepção dialógica. Esse reconhecimento exige, a nosso ver, um saber prévio por parte do leitor, um conhecimento dos textos que se interpenetram dialogicamente na estrutura do texto.

Para Jauss, somente na relação dialógica da obra com o leitor é que se concretizam o caráter estético e o papel social da arte. Voltado para a experiência estética como momento de prazer, formula os conceitos de fruição compreensiva e compreensão fruidora - o leitor gosta daquilo que compreende e só poderá compreender aquilo que aprecia -, sendo o prazer e a compreensão processos simultâneos (JAUSS, 1979, p.16): 
O prazer estético que, desta forma, se realiza na oscilação entre a contemplação desinteressada e a participação experimentadora, é um modo da experiência de si mesmo na capacidade de ser outro, a capacidade a nós aberta pelo comportamento estético (JAUSS, 1979b, p.77).

Jauss introduz, assim, as três categorias básicas retiradas da tradição estética, que explicitariam a experiência estética da obra em relação ao seu emissorcriador e receptor, que pode tornar-se seu coprodutor: poiesis, aisthesis e katharsis. Segundo o autor, a poiesis remete ao "prazer ante a obra que nós mesmos realizamos" (JAUSS, 1979b, p. 79); a interação entre texto e leitor possibilita ao segundo tornar-se coprodutor da criação literária. Já a aisthesis se concretiza por meio do efeito, ou seja, o leitor reconhece os elementos representados e renova o seu conhecimento sobre esses elementos, no que Jauss designa de "o prazer estético da percepção reconhecedora e do reconhecimento perceptivo" (JAUSS, 1979b, p. 80). A katharsis designa "aquele prazer dos afetos provocados pelo discurso ou pela poesia, capaz de conduzir o ouvinte e o expectador tanto à transformação de suas convicções, quanto à liberação de sua psique" (JAUSS, 1979b), isto é, por meio da identificação entre os elementos da narrativa e o leitor se processa a katharsis, que não se restringe somente à liberação das emoções, como também é catalisadora de ação, levando o leitor à reflexão frente à sua realidade. Correspondem essas três funções básicas aos aspectos de produção, recepção e comunicação, que conservam o seu caráter de experiência estética, desde que fique mantido o caráter de prazer.

As pesquisas de Jauss se direcionam, então, para a reconstrução histórica da forma como o texto foi recebido e interpretado por leitores diversos ao longo do tempo e o seu efeito atual, resultando na fusão de dois horizontes: o do autor, que construiu sentido, e o do público, que (re) interpreta o sentido em confronto com o tempo atual. A objetivação do horizonte de expectativa é possível através 
daquelas obras que, adotando uma convenção (seja de gênero, estilo ou de forma), evocam um horizonte de expectativa para logo abandoná-lo ou destruí-lo (o autor exemplifica com as obras Dom Quixote e Jacques, o fatalista), bem como em obras "historicamente menos delineadas" (JAUSS, 1994, p. 29).

A estética da recepção adota como critério de determinação do valor estético da obra literária o seu poder de decepcionar ou contrariar as expectativas leitoras no momento de sua aparição, isto é, "a distância entre o horizonte de expectativa e a obra, entre o já conhecido da experiência estética anterior e a "mudança de horizonte"' (JAUSS, 1994, p. 31). A redução dessa distância é comum na arte ligeira ou "culinária", pois fica dentro dos limites do conhecido e do esperado e não exige do leitor nenhuma mudança. Tal fato pode ocorrer, também, com obras literárias que, no momento de aparição, eram inovadoras e, depois, para o leitor atual, se tornam óbvias.

Faz-se importante a reconstituição do horizonte de expectativa de criação e recepção da obra literária, uma vez que essa pode propiciar indicadores de como determinada obra foi recebida pelo público leitor, permitindo que se desvende a pergunta desse mesmo público à qual a obra respondeu no momento de sua aparição (lógica da pergunta e da resposta). No entanto, a reconstituição da pergunta não se encontra mais no horizonte primeiro e original, ele já está contaminado pelo horizonte atual. Assim, a compreensão histórica da obra implica uma fusão de horizontes, resultando, também, numa consciência da história dos efeitos, já que a obra foi, ao longo do tempo, acumulando interpretações e recepções.

Para Bakhtin, o discurso, em sua gênese dialógica, está, também, orientado para o discurso-resposta, antecipando o que não foi dito, mas já era esperado. Essa orientação para o ouvinte/leitor pressupõe uma atitude ativa de sua parte. Temos, assim, dois tipos de dialogicidade interna: um em que o objeto é arena de encontro de discursos diversos e outro que se volta para o círculo subjetivo do leitor. Essa dialogicidade interna do discurso 
não é fonte de estudo da linguística, já que lhe interessa o diálogo enquanto forma composicional da construção do discurso. Ao ouvinte cabe um papel passivo.

O estilo poético prima pela unicidade da linguagem. Esse caráter monologicamente fechado fixa o impedimento da entrada para a ideia de pluralidade lingüística; não concebe a interação com o discurso alheio, eliminando de seu contexto todo o plurilinguismo. O gênero poético acaba por se caracterizar enquanto linguagem autoritária, dogmática e conservadora. O gênero romanesco, por sua vez, convive com diferentes linguagens literárias e extraliterárias. $O$ prosador não purifica seu discurso, ao contrário, orquestra no seu interior toda uma gama de diversidade linguística, estilística e concepções de mundo... "O prosador utilizase de discursos já povoados pelas intenções sociais de outrem, obrigando-os a servir às suas novas intenções, a servir a seu segundo senhor" (BAKHTIN, 1993, p. 105). O romance é, para Bakhtin, o gênero por excelência, que, em seu conjunto, se caracteriza por ser um fenômeno pluriestilístico, plurilíngue e plurivocal.

Os discursos literários são classificados, por Bakhtin, em monológicos ou dialógicos, conforme a relação estabelecida com os tipos de discurso introduzidos na composição do romance, podendo exercer a função de mera reprodução ou contestação da norma clássica. No romance monológico, as outras vozes são abafadas pela interpretação e avaliação do autor, resultando num discurso autoritário, dogmático e, por consequência, conservador; esse discurso soa como se fosse um sistema acabado de uma única voz, daí seu caráter de discurso monovocal. O romance dialógico, por sua vez, entrecruza, na sua composição romanesca, uma multiplicidade de situações linguísticas, que combinam diferentes discursos. Nesse discurso, a palavra adquire dupla significação, torna-se ambivalente, daí seu caráter de discurso bivocal.

Bakhtin traça uma distinção entre oração e enunciado. A oração, enquanto unidade da língua, tem seu contexto discursivo restrito a um único e mesmo 
${ }^{3}$ Quando de seus primeiros escritos, Bakhtin já introduz a arquitetônica da responsabilidade ou da respostabilidade, isso é, a literatura de um texto sempre exige a sua compreensão, mas uma compreensão que se configura como réplica; corresponde a uma resposta, uma reação por parte do leitor perante o texto lido. sujeito falante; sua natureza gramatical traça as fronteiras de acabamento dentro da própria gramática. Por sua vez, o enunciado, unidade da comunicação verbal, se caracteriza justamente pelo diálogo com o outro e pela espera de uma resposta. Essa resposta Bakhtin denomina de "compreensão responsiva ativa"3.

$\mathrm{O}$ ouvinte que recebe e compreende a significação (linguística) de um discurso adota simultaneamente, para com este discurso, uma atitude responsiva ativa: ele concorda ou discorda (total ou parcialmente), completa, adapta, apronta-se para executar etc., e esta atitude do ouvinte está em elaboração constante durante todo o processo de audição e de compreensão desde o início do discurso, às vezes já nas primeiras palavras emitidas pelo locutor. A compreensão de uma fala viva, de um enunciado vivo é sempre acompanhada de uma atitude responsiva ativa (conquanto o grau dessa atividade seja muito variável) toda compreensão é prenhe de resposta e, de uma forma ou de outra, forçosamente a produz: o ouvinte torna-se locutor (BAKHTIN, 1992, p. 245).

A alternância dos sujeitos falantes é a primeira particularidade que distingue enunciado e oração. A segunda particularidade, indissociável da primeira, é o acabamento do enunciado que tem na possibilidade de responder o seu mais importante critério, o qual é determinado por três fatores: o tratamento exaustivo do objeto do sentido, o querer-dizer do locutor e as formas estáveis do gênero do enunciado.

Em sua última tese, Jauss aponta, sobretudo, para o caráter emancipatório da obra literária, que, ao apresentar o novo, desautomatiza as expectativas do leitor, apresentando-lhe um horizonte diverso do habitual.

O horizonte de expectativa da literatura distingue-se daquele da práxis histórica pelo fato de não apenas conservar as experiências 
vividas, mas também antecipar possibilidades não concretizadas, expandir o espaço limitado do comportamento social rumo a novos desejos, pretensões e objetivos, abrindo, assim, novos caminhos para a experiência futura (JAUSS, 1994, p. 32).

Jauss define, dessa forma, as duas possibilidades de concretização do texto literário pelo leitor: uma orientada para o horizonte implícito de expectativa e outra para a análise das expectativas externas à obra, relacionadas à vivência do leitor. No primeiro, de cunho intraliterário, o efeito é condicionado pela obra, o leitor implícito, criação ficcional, depende das estruturas objetivas da obra. No segundo, de cunho extraliterário, a recepção é condicionada pelo leitor; o leitor explícito depende de fatores externos à obra literária (ZILBERMAN, 1989, p.65).

\section{Onde se poderia ler conclusão}

Nem tão perto nem tão longe, assim podemos dizer que se encontram as ideias desenvolvidas por Bakhtin e Jauss. Apesar de Bakhtin não pensar a obra em relação dialógica com a sua época e nem de Jauss levar em conta a relação dialógica entre discursos, os dois autores têm como elemento comum a noção de dialogismo. Ambos consideram o leitor como elemento ativo que vivifica a obra. Para Bakhtin, a relação dialógica com o leitor se legitima pelo plurilinguismo, isto é, as várias formas de manifestação da linguagem, enquanto, para Jauss, ela é estabelecida pela leitura.

Na concepção de Bakhtin, a palavra constitui um elo entre vários discursos. Ela não é estática, mas um signo social dialético, dinâmico e vivo, por isso, ativa e mutável; portanto, nunca é neutra e está sempre a serviço de algo, carregando consigo as interpretações e pressões dos contextos que já integrou. Bakhtin vinculou o texto literário à história e à sociedade, vistos como outros “textos" possíveis de leitura. Assim, todo texto comportaria 
o diálogo de vários discursos: do emissor, do destinatário e do contexto e/ou contextos anteriores. O escritor já não é o "Adão bíblico" em busca do verbo primeiro, à medida que todo discurso está sempre habitado por outras vozes, por outros discursos.

Percebe-se, desse modo, que a essência do princípio dialógico se fundamenta como tal numa relação de alteridade, ou seja, o processo de comunicação exige o reconhecimento do outro. Na perspectiva bakhtiniana, o permanente processo de dialogização vai refletir na relação dinâmica estabelecida entre o autor, o texto literário e o leitor, pois a palavra, enquanto criação ideológica, vai desenvolver-se de forma diversa das normas estabelecidas. A pluralidade de vozes inseridas no discurso romanesco revela ao leitor um horizonte diverso do habitual.

Se lembrarmos a afirmação de mero reproduzir as normas (característica do discurso monológico) e a contestação dessas normas (característica do discurso dialógico) observa-se que o romance dialógico estabelece um diálogo, de caráter crítico e reflexivo sobre as normas estabelecidas, com o leitor. Pode-se dizer, então, que, mesmo sem a intenção primeira, as ideias de Bakhtin se aproximam da ideia de emancipação promovida pela leitura do texto literário formulada por Jauss.

Já a existência simultânea de várias vozes, de vários discursos no texto, acaba por fraturar a ideia de sucessão linear da literatura. Dessa forma, Bakhtin, ao debruçar-se sobre o diálogo com a tradição ou ao se deter na história da literatura do ponto de vista do plurilinguismo, também, como Jauss, constrói a história da literatura por outro viés que não se faz continuum e homogêneo. Ao conceber a existência de, no mínimo, duas vozes, Bakhtin coloca em foco e traz à tona, como Jauss, o recebedor do texto: o leitor.

Poderíamos então nos perguntar: qual a relevância desses autores para a crítica contemporânea? Sem sombra de dúvida, a atualidade das reflexões desenvolvidas 
por eles é visível nos estudos desenvolvidos na área de letras, em especial da Teoria Literária, desde que leve em conta o leitor. Tanto a Estética da Recepção, que tem em Jauss um de seus representantes, como o estudo do dialogismo, aqui representado por Baktin, são linhas teóricas que auxiliam na compreensão do discurso literário contemporâneo. 


\section{Referências}

BAKHTIN, Mikhail M. Gêneros do discurso. In: BAKHTIN, Mikahil. Estética da criação verbal. São Paulo: Martins Fontes, 1992.

BAKHTIN, Mikhail. Questões de literatura e de estética: a teoria do romance. 3. ed. Trad. Aurora Fornoni Bernadini. São Paulo: Unesp/Hucitec, 1993.

BAKHTIN, Mikhail. Problemas da poética em Dostoiévski. Rio de Janeiro: Forense-Universitária, 1981.

BAKHTIN, Mikhail. Marxismo e filosofia da linguagem. São Paulo: Hucitec, 1992.

JAUSS, Hans Robert. A história da literatura como provocação à teoria literária. Trad. Sérgio Tellaroli. São Paulo: Ática, 1994.

JAUSS, Hans Robert. A estética da recepção: colocações gerais. In: LIMA, Luiz Costa (Org.). A literatura e o leitor. Rio de Janeiro: Paz e Terra, 1979a.

JAUSS, Hans Robert. O prazer estético e as experiências fundamentais da poiesis, aisthesis e katharsis. In: LIMA, Luiz Costa (Org.). A literatura e o leitor. Rio de Janeiro: Paz e Terra, $1979 b$.

ZILBERMAN, Regina. Estética da recepção e história da literatura. São Paulo: Ática, 1989. 